JOURNAL OF SECURITY AND SUSTAINABILITY ISSUES

ISSN 2029-7017 print/ISSN 2029-7025 online

2019 September Volume 9 Number 1

http://doi.org/10.9770/jssi.2019.9.1(4)

Scopus

\title{
ENSURING COMPLEX SECURITY OF THE FINANCIAL FLOWS MOVEMENT IN THE NATIONAL ECONOMY SYSTEM
}

\author{
Liudmyla Katan', Iuliia Masiuk², Tetyana Oliynik3, Oleg Oliynik4, Volodymyr Zablotskyi5

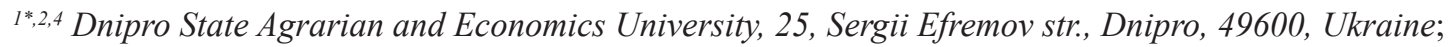 \\ ${ }^{3}$ Oles Honchar Dnipro National University, 35, Yavornitskogo str., Dnipro, 49000, Ukraine; \\ ${ }^{5}$ Luhansk Taras Shevchenko National University, 1, Gogol Square, 92703, Starobilsk, Ukraine \\ E-mail:1*koaduep@gmail.com
}

Received 15 November 2018; accepted 28 June 2019; published 30 September 2019

\begin{abstract}
The individual principles of the cyclical course of economic processes in modern economic conditions were considered. The existing theories of economic (business) cycles were analyzed. The financial economy was defined as a component of the security of financial flows. The factors of strengthening (weakening) of the interaction of financial flows in the economy and their safe movement support were characterized. The effect of multiplication of financial flows for individual stages of the economic cycle was disclosed. The specifics of complex security of the movement of financial flows in industrial and financial economies were studied. A comparative characteristic of industrial and financial economies was carried out according to a number of criteria.
\end{abstract}

Keywords: security of the financial flows movement, financial flow, industrial economy, financial economy, development, economic cycle, financial sector, real sector

Reference to this paper should be made as follows: Katan, L.; Masiuk, I.; Oliynik, T.; Oliynik, O.; Zablotskyi, V. 2019. Ensuring complex security of the financial flows movement in the national economy system, Journal of Security and Sustainability Issues 9(1): 39-50: http://doi.org/10.9770/jssi.2019.9.1(4)

JEL Classifications: F52, O39

\section{Introduction}

The modern economic environment is characterized by a high level of uncertainty of processes, an increase in the number and quality of crises, an increase in the volume of «soap bubbles» and especially significant consequences of their «collapses» for the security of financial flows movement in economic systems. The gradual transformation of the crisis into an economic one, although it does not resemble a succession of a major economic depression, in fact, has similar consequences. Recessionary processes slowly cover the whole world - from countries with a lower level of economic development to highly developed ones. China remains a successful exception to the crisis, although its economy also shows a slowdown in economic growth (Tvaronavičiene, 2019a, 2019b). In general, the crisis processes determined the need to consider the issue of economic security and the development trends of national economies for decades to come. The need for timely prevention of the described crisis phenomena determines the relevance of more detailed studies of the fundamentals of the financial flows movement by types of economies.

The works of many well-known scientists, such as Amicelle, 2011; Best, 2017; Bodie, et. al. 2005; de Goede, 2017; Gilbert, 2017; McCloskey, 2016; Hilkevics, Hilkevica, 2017; Masood et al., 2019 are devoted to the theoretical and practical fundamentals of the study of the financial flows movement and their security in economic systems. 
However, certain principles of such a movement, taking into account the peculiarities of modern economic development and deployment of processes for initiating the security of the financial flows movement are still insufficiently studied and require further scientific study. The subject of this study is the mechanism of cyclical economic processes, which manifests itself through the appropriate interaction of financial flows in industrial and financial economies.

The purpose of the article is to study the specifics of the financial flows movement in industrial and financial economies by conducting a comparative analysis on a number of characteristic criteria of these economies.

\section{Literature Survey}

The considerations by economists of the mechanism of the occurrence and existance of economic processes, taking into account cyclicality and security, have been formed over a long period of time. The theory of cycles was developed by economist M. Kondratiev, who empirically established the presence of large waves of the economic conditions of capitalist countries. M. Kondratiev analyzed the dynamics of changes in various macroeconomic indicators in countries such as England, France, Germany, and the United States from the end of the 18th century to the beginning of the 20th. After processing the data, M. Kondratiev detect the presence of fluctuation cycles of the parameters studied for a duration of 48-55 years. Despite the fact that the period under consideration (140 years) is quite short by historical standards (only 2.5 waves of a large cycle), M. Kondratiev concluded that there is a high probability of the existence of large cycles of economic conditions. Crises associated with changes in technology accompany the entire history of mankind and can be viewed as a general civilizational regularity. Based on his observations, M. Kondratiev made a long-term forecast until 2010, including, in particular, the Great Depression of the 1930s (Bodie, et. al. 2005).

The well-known scientist S. Kuznets, based on extensive empirical study, revealed the existence of long-term (approximately 22 years) fluctuations in the dynamics of production and prices, which confirmed the existence of economic cycles (Fabozzi, et. al. 2002).

The development of the theory of economic cycles created a new dichotomy between economic theories, given the need to explain both large cycles (which was possible within the dialectical approach) and minor fluctuations of the economy (which required the development of a systems approach). Therefore, in the beginning of the 1980 s, in connection with the creation of a theory of real business cycles, a shift in research focus is observed from the analysis of growth processes to the analysis of the fluctuation behavior of economic activity. Similarly to the fact that long-term growth is explained by exogenous factors in the model of R. Solow, short-term fluctuations in studies of theorists of real business cycles are also explained by exogenous factors. Although the canonical model of real business cycles concerns only the analysis of fluctuations, which are interpreted as the optimal responses (fssdbacks) of business entities to exogenous real shocks, the long-term dynamics of economic growth remain neglected. Schumpeter's view of business cycles (especially recessions) as a mechanism for reducing (or eliminating) organizational imperfections or inefficient allocation of production factors found its recovery in the works of (Delas, et. al. 2015; Hall, and Soskice, 2001). Thus, endogenous and exogenous factors are partially combined in explaining the existence of cycles. The significance of exogenous factors in cyclic processes is displayed in the works of (Elton, et. al. 2003; Massumi, 2014).

However, exogenous and endogenous factors are taken separately from each other, that is associated with the efficiency of the national economy. The legitimacy of the traditional division of macroeconomic theory into trend and cyclical components was called into question in the $80 \mathrm{~s}$ when work on real business cycles appeared (Arnold, 2004), in which it was noted that productivity shocks are the main driving force of cyclical fluctuations. This became the basis for the revival of the Schumpeter's point of view on growth and cycles as a single economic phenomenon. The main group of models explaining economic fluctuations is based on the assumption of non-equilibrium dynamics of individual elements of economic systems, representing a systemic perception of economic processes (Dalevska et al., 2019). 


\section{Methods}

The approach of the theory of real business cycles is very close to determining the causal relationships between the growth of productivity of production factors and economic fluctuations, and their influence and the security of financial flows. In particular, in the model of R. Goodwin (Bodie, et. Al. 2005) there are economic fluctuations that were modeled as deterministic accompaniment of the process of economic growth, or rather, variations in income distribution (between salary and profit), which are the result of the growth process. Using the stochastic version of economic growth, emphasizing real productivity shocks as perhaps the only source of economic fluctuations to explain the pro-cyclical behavior of consumption and employment, using the balance of $\mathrm{R}$. Solow in order to measure variations in the use of capital and labor during periods of business cycles, the creators of the theory of real business cycles worked their way to for the next turning point in study of growth and macroeconomic fluctuations. Such a turning point, indeed, took place when scientists independently modeled the presence of an endogenous trend in the theory of real (or monetary) business cycles Since the endogenous nature of the trend of cycles was not explained by the non-equilibrium dynamics of the elements of the system, the systematic approach was not fully adequate in this case.

\section{Results}

The following growth models or business cycles get rid of the assumption of non-equilibrium, but nevertheless avoid explaining the complex problem of the relationships between the growth trend and business cycles. This concerns both the well-known growth model of R. Solow and the later versions of this model before the appearence of endogenous growth studies, in which, as before, the long-term trend was the result of either population growth or exogenous technical progress. Thus, there is a dichotomy between theories of growth and theories of cycles (Naudé, \& Szirmai, (2013).

The fact is that, both in growth studies and fluctuation studies, macroeconomic time series were considered stationary for a long time, which meant that the economic system could not deviate permanently from its equilibrium growth trajectory after exposure to one or another shock; such deviations were considered temporary. However, the work (Sachs, 2016) on the stochastic nature of the main macroeconomic indicators, with its conclusion that temporary shocks can have a permanent impact on the long-term dynamics of economic processes, revealed an urgent need to reform the existing relationships between growth and fluctuations and provide these relationships into clear status of integration.

A reflection of the dualistic perception of economic processes are also contradictions in the characteristics of the causes of economic cycles, representatives of the theory of real economic cycles and the new Keynesian theory. The theory of real economic cycles is characterized by the following scientific works: (Bottazzi, et. al. 2008; Brealey, et. al. 2007; Corman, et. al. 2012b).

Scientists (Delas, et. Al. 2015; Haugen, (2001) remaining on the fundamental positions of Keynesianism, concentrate efforts on microeconomic phenomena. Considering that the emergence of the economic cycle is caused by demand shocks, these scientists try to find out which factors prevent firms from quickly adapting to changes in the situation and restoring equilibrium. Also, the "new Keynesians" insist that the balance concepts of F. Cüdland and V. Prescott cannot explain the reasons for significant recessions. Another source of nonequilibrium in the models of «new Keynesians» is limited access to information, as evidenced by the works of (Huber, et. al. 2010; Langley, 2015; Laster, et. al. 2016; Rudman, 2013). The same can be said about other models of business cycles that have been formed in the framework of market equilibrium or obvious nonlinearities in inter-hour preferences; However, none of these models gave a clear picture of the existence of a trend in its relation (possibly causal) to fluctuations. The driving forces of cyclical nature are so diverse that their concentrated embodiment is almost impossible. One of the main aspects of the manifestation of the cyclical nature of economic processes is, in our opinion, the cyclical nature of the movement and interactions of financial flows; it manifests itself in the most concentrated way through the differences in the cyclic nature of the industrial and financial economy (Dobrovolskienè et al., 2017; Isatayeva et al., 2019). 
The determining factor in strengthening/weakening of the interaction of financial flows is their structuring and multiplication (Drobyazko S., 2017; Drobyazko S., Hryhoruk I., Pavlova H., Volchanska V., Sergiychuk S., 2019). The prerequisites for increase in money supply are included in the institutional mechanisms for its regulation. However, the material basis of social production is the basis for the formation of value added, and then determines the volume of money supply. In the industrial economy, the real sector dominates the financial one, the material basis of social production is broad, which determines the high level of match of the commodity and money supply (Fig. 1).

The multiplication effect at the growth stage contributes to the fact that the money supply grows at a higher rate than the commodity, which determines its direction to the financial sector. The financial sector at the growth stage controls an increasing share of financial flows, respectively, through control over financial flows, it strengthens control over the real sector - the processes of convergence of the financial and real sectors become the basis of structural changes in the economy. However, at this stage, the multiplication effect is not so significant that it can lead to the formation of turbulent financial flows. On the contrary, their fluctuations mutually compensate each other, which makes it possible to use financial instruments to diversify minor turbulences of financial flows. In general, at this stage financial flows are laminar.

At the plateau stage, when the growth of the commodity mass is insignificant, the monetary mass continues to grow through lag, the amount of financial resources becomes redundant, which leads to a 


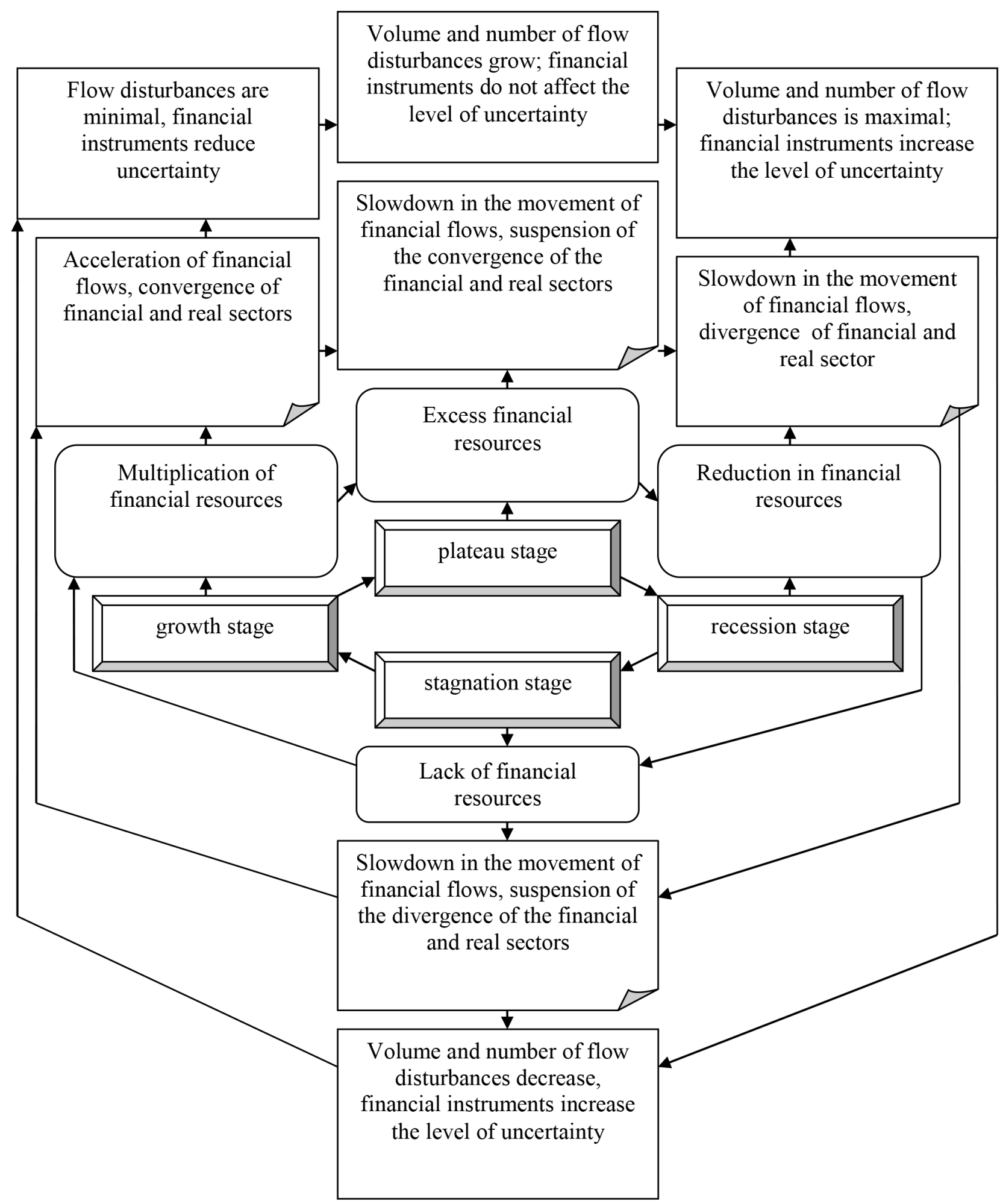

Fig. 1. Specifics of movement and violation of security of the financial flows movement in the industrial economy

Source: Designed by the authors 


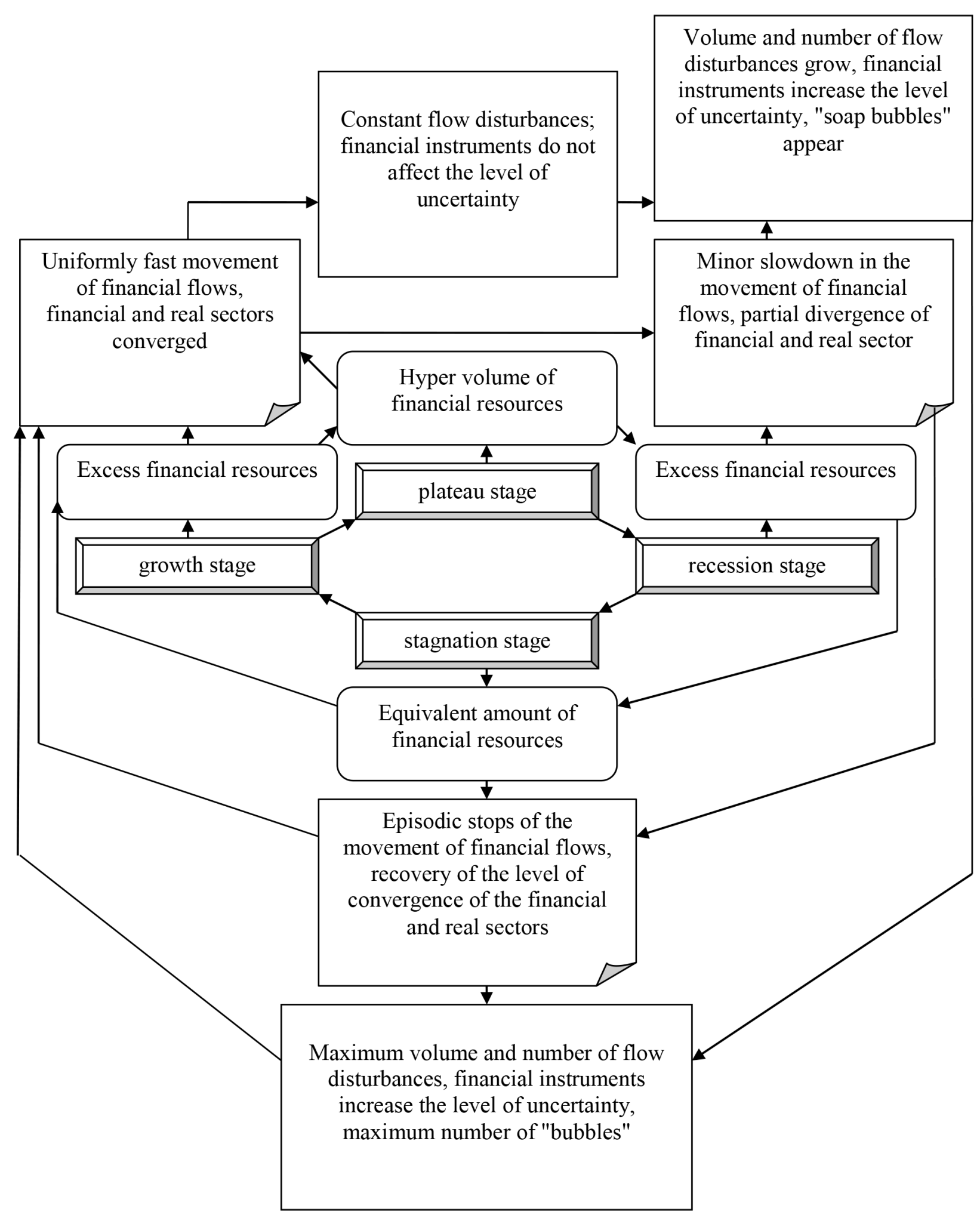

Fig. 2. Specifics of movement and violation of security of the financial flows existence in the financial economy Source: Designed by the authors 
decrease in the speed of movement of financial flows and inflation. These effects are widely described in the scientific literature. The redistribution of free financial resources towards the financial sector due to a decrease in the efficiency of operations in the real sector causes a slowdown in the convergence of the financial and real sectors. At the same time, due to the slowdown in the movement of financial flows, their interaction intensifies, which determines an increase in turbulence. The diversification effect becomes ineffective in compensating for random fluctuations of financial flows, financial instruments contribute to the multiplication of money supply, increasing the level of uncertainty in financial processes. At the end of this stage, the dichotomy of development trends is possible (Amadae, 2018).

First, the likelihood of significant sources of turbulence in financial flows through institutional factors, external influences, leakage of insider information, and the like becomes high. These effects become the obstacle in the movement of financial flows, even in their laminar state can cause significant turbulence. In a condition where there is always a very significant impact of sources of uncertainty, such effects may be systemic. However, since the main financial flows circulate in the financial sector, first of all, systemic violations occur in this sector, and only then induced to the real sector, convertible from financial (Tvaronavičienè, 2019a).

Secondly, without the occurrence of obstacles in moderately turbulent financial flows, a slow and then everincreasing decrease in the volume of financial resources begins first due to a decrease in multiplication amid rising inflation and a rise in the cost of resources. The main factor in the depth of the recession in this case is the duration of the lag and the effectiveness of the monetary mechanism. Due to the decrease in the volume of financial resources, the convergence of the financial and real sectors stops and can be transformed into a divergence. Again, the main factor is that in the industrial economy, the real sector is a source of added value. Since financial flows in the sector are predominantly laminar, sources of turbulence are minimized (Wit, and Meyer 2005).

Significant differences have regularities in the movement of financial flows in the so-called "financial economy" (Fig. 2), the distinctive feature of which is the proportional ratio of the real and financial sectors or the domination of the financial sector over the real.

In a rapidly changing economic environment, tough competition, financial sector entities should not only focus on the state of affairs of their internal environment, but also develop a long-term financial management strategy that would allow them to adapt to the changes taking place in their environment. The issues of improving the system of strategic planning in the activities of domestic entities of the financial sector are of particular importance. Management of a financial sector entity involves the efficient formation and use of financial resources in relevant areas of activity. At the same time, the issues of financial resources management within the achievement of the strategic objectives of the individual subjects of the financial sector are relevant - expanding the coverage of the market field of activity, ensuring the balance of the financial services portfolio, improving the quality of financial products offered on the market. Therefore, strategic financial decisions of financial sector entities should be formed from the standpoint of the integrated interaction of the external market and internal organizational environment of each of these entities.

Financial flows of financial sector entities, which are defined as input and output, are interdependent on the stages of the life cycle of the market products of these entities (Table 1).

At the same time, a consistent change in the stages of introduction, growth, maturity and recession determines the competitive position of the financial sector entity in the market. 
Table 1. Main financial flows of financial sector entities

\begin{tabular}{|c|c|c|c|c|}
\hline \multirow{2}{*}{ Entities } & \multicolumn{4}{|c|}{ Stages of product life cycle } \\
\hline & Introduction & Growth & Maturity & Recession \\
\hline $\begin{array}{l}\text { Input } \\
\text { flows }\end{array}$ & $\begin{array}{l}\text { Investments in } \\
\text { authorized capital; } \\
\text { Insignificant amount } \\
\text { of initial contributions } \\
\text { at the conclusion of } \\
\text { transactions }\end{array}$ & $\begin{array}{c}\text { Initial contributions; } \\
\text { Investment income; Revenues } \\
\text { from the results of risk } \\
\text { redistribution; } \\
\text { Revenues from financial } \\
\text { transactions }\end{array}$ & $\begin{array}{l}\text { Financial contributions; } \\
\text { Investment income; } \\
\text { Revenues from the results of } \\
\text { risk redistribution; } \\
\text { Revenues from financial } \\
\text { transactions }\end{array}$ & $\begin{array}{l}\text { Financial contributions; } \\
\text { Investment income; } \\
\text { Revenues from financial } \\
\text { transactions }\end{array}$ \\
\hline $\begin{array}{l}\text { Output } \\
\text { flows }\end{array}$ & $\begin{array}{l}\text { High advertising } \\
\text { costs; Agent network } \\
\text { financing; } \\
\text { Contract preparation } \\
\text { costs; Remuneration } \\
\text { of employees of the } \\
\text { financial sector entity; } \\
\text { Deductions to the } \\
\text { special fund of financial } \\
\text { resources }\end{array}$ & $\begin{array}{l}\text { Financing damage; } \\
\text { Remuneration of financial } \\
\text { intermediaries; Costs of } \\
\text { maintaining (implementing) } \\
\text { contracts; Expenses for the } \\
\text { redistribution of risks; } \\
\text { Remuneration of employees } \\
\text { of the financial sector entity; } \\
\text { Investments; Deductions to } \\
\text { the special fund of financial } \\
\text { resources }\end{array}$ & $\begin{array}{l}\text { High marketing costs; } \\
\text { Financing damage; } \\
\text { Remuneration of financial } \\
\text { intermediaries; Costs of } \\
\text { maintaining (implementing) } \\
\text { contracts; Expenses for the } \\
\text { redistribution of risks; } \\
\text { Remuneration of employees } \\
\text { of the financial sector entity; } \\
\text { Investments; Deductions to } \\
\text { the special fund of financial } \\
\text { resources }\end{array}$ & $\begin{array}{l}\text { High sales support costs; } \\
\text { Financing damage; } \\
\text { Remuneration of financial } \\
\text { intermediaries; Costs of } \\
\text { maintaining (implementing) } \\
\text { contracts; Expenses for the } \\
\text { redistribution of risks; } \\
\text { Remuneration of employees } \\
\text { of the financial sector entity; } \\
\text { Investments; Deductions to } \\
\text { the special fund of financial } \\
\text { resources }\end{array}$ \\
\hline
\end{tabular}

Source: Jaconetti, et. al. (2016); World Economic Forum (2018).

The level of performance of financial resources management of a financial sector entity is an assessment of the degree of achievement of strategic goals and tactical tasks of the formation and use of financial resources according to indicators of socially significant, final and immediate results (Nanto, 2011). Performance evaluation is formed by the correlation of strategic goals and tactical tasks of managing financial resources within the financial operations of the studied entity of financial sector and the results obtained by it.

\section{Discussion}

The level of performance of financial resources management of a financial sector entity is determined in stages. At the first stage, the main types of financial products are determined. At the second stage, the strategic goals and tactical tasks of the formation and use of financial resources are set. At the third stage, a list of financial transactions of the financial sector entity is formed within the limits of the outlined goals and objectives. The fourth stage is characterized by the formation of a system of indicators for the relevant financial transactions and their values. At the fifth stage, the nature of the effect of indicators is determined: direct or reverse. At the sixth stage, the deviations of the values of the indicators for the direct effect and / or for the reverse effect are determined. At the seventh stage, the scores of indicators are formed on the basis of calculations of their deviations by values (unit of deviation of the indicator value corresponds to the unit of scoring). At the eighth stage, experts determine the shares of the indicators depending on their significance within the limits of the previously defined goals and tasks (the sum of the shares of the indicators for the goals and tasks within one financial product is 1) (King's College London (2017). At the ninth stage, indices of the result are calculated by indicators by multiplying the scores of the indicators by their respective shares. At the tenth stage, the indices of the result for all financial transactions (the sum of the indices of the result by the indicators in the context of individual transactions) and the final index of the result (the sum of all the indices of the result for the operations) are calculated (Wei, 2015). The strategic goal, tactical tasks, socially significant, final and immediate indicators of the effectiveness of the formation and use of financial resources of the financial sector entities within a number of financial transactions are presented in Table 2. 
Table 2. Components of strategic management to ensure the effectiveness of the formation and use of financial resources of the financial sector entities of the national economy

\begin{tabular}{|c|c|c|c|c|c|}
\hline Strategic goal & $\begin{array}{l}\text { Socially significant } \\
\text { indicators }\end{array}$ & Tactical tasks & $\begin{array}{c}\text { Entity } \\
\text { transactions }\end{array}$ & Immediate indicators & Final indicators \\
\hline \multirow{3}{*}{ 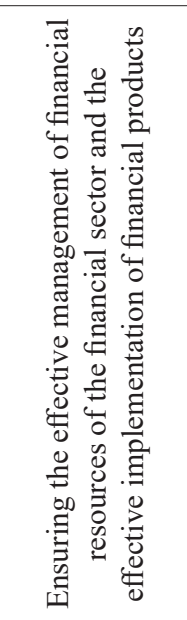 } & \multirow{3}{*}{ 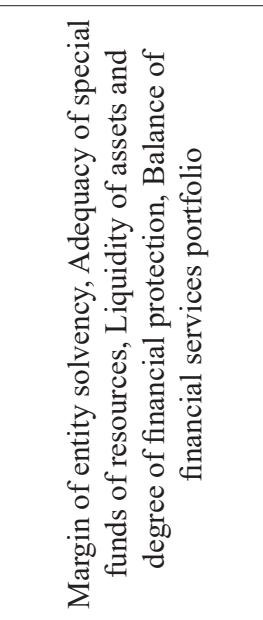 } & $\begin{array}{l}\text { Expansion of } \\
\text { activity field } \\
\text { coverage }\end{array}$ & 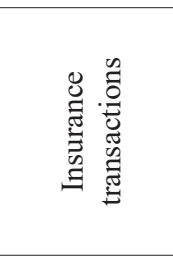 & $\begin{array}{l}\text { Volume of bonuses; } \\
\text { Volume of payments; } \\
\text { Amount of reserves; } \\
\text { Number of contracts } \\
\text { concluded; } \\
\text { Income from operating } \\
\text { activities }\end{array}$ & $\begin{array}{l}\text { Profitability of transactions; } \\
\text { Ratio of the amount of bonuses } \\
\text { and reserves }\end{array}$ \\
\hline & & $\begin{array}{l}\text { Optimization } \\
\text { of return from } \\
\text { investment }\end{array}$ & 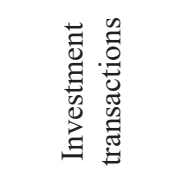 & $\begin{array}{l}\text { Volume of investments; } \\
\text { Investment income; } \\
\text { Number of investment } \\
\text { fields }\end{array}$ & $\begin{array}{l}\text { Efficiency of investment } \\
\text { transactions; } \\
\text { Investment return level }\end{array}$ \\
\hline & & $\begin{array}{c}\text { Increase in } \\
\text { financial potential } \\
\text { of financial sector } \\
\text { entities }\end{array}$ & 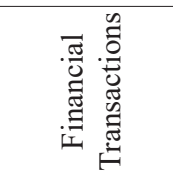 & $\begin{array}{c}\text { Equity capital; } \\
\text { Net assets; } \\
\text { Income from financial } \\
\text { activities }\end{array}$ & $\begin{array}{c}\text { Return on equity; Ratio of } \\
\text { equity and liabilities; Ratio of } \\
\text { current and non-current capital }\end{array}$ \\
\hline
\end{tabular}

Source: Standard and Poor's (2007); UN Security Council (2017).

The competitive advantage of the financial services portfolio of financial sector entities can be characterized by a set of the following indicators: size of the price; separate rules of activity; number of new financial products; term of activity; scope of responsibility of entities and others. The level of development of the financial sector can be characterized by a set of the following indicators: number of types of financial services, development of risk redistribution mechanisms, world market situation, availability of government programs to stimulate the development of innovative types of financial services, etc. The stability of the economic conditions in a country can be characterized by a set of the following indicators: effective demand, tax system, types of alternative sources of financing, the state of individual segments of the financial market, inflation and interest rates, nature of the liability, etc. (Wallick, et. al. 2012).

Each of the presented indicators can be estimated in the range from 1 to 10 . On the basis of the obtained values of the indicators, the average statistical evaluation of the criterion is derived (Langenohl, 2017; Yan, 2012). After that, all the resulting average values of the criteria are entered into a special scheme of distribution of market forces.

The consequence of differences in the mechanism of cyclicity is a significant difference between industrial and financial economies with their characteristic properties (Table 3).

Table 3. Comparative characteristics of industrial and financial economies in the framework of economic security

\begin{tabular}{|c|l|l|}
\hline Characteristics & \multicolumn{1}{|c|}{ Industrial economy } & \multicolumn{1}{|c|}{ Financial economy } \\
\hline $\begin{array}{c}\text { Topology of } \\
\text { financial space }\end{array}$ & $\begin{array}{l}\text { Does not change within the cycle and during the } \\
\text { transition from cycle to cycle }\end{array}$ & $\begin{array}{l}\text { Does not change within one cycle, changes during a system } \\
\text { crisis }\end{array}$ \\
\hline $\begin{array}{c}\text { Ratio of real and } \\
\text { financial sectors }\end{array}$ & $\begin{array}{l}\text { The real sector in terms of financial resources } \\
\text { significantly exceeds the financial one }\end{array}$ & $\begin{array}{l}\text { The real sector and the financial sector even out in terms of } \\
\text { financial resources, the financial sector begins to dominate }\end{array}$ \\
\hline $\begin{array}{c}\text { Features of the } \\
\text { movement of } \\
\text { financial flows }\end{array}$ & $\begin{array}{l}\text { The patterns of movement of financial flows within } \\
\text { the financial and real sectors are specific, containing } \\
\text { constant characteristics, fluctuations in financial } \\
\text { flows within the real sector are insignificant. }\end{array}$ & $\begin{array}{l}\text { Fluctuations of financial flows within the financial and real } \\
\text { sectors acquire the same characteristics, the patterns of } \\
\text { movement lose their specificity }\end{array}$ \\
\hline $\begin{array}{c}\text { Convergence of } \\
\text { the financial and } \\
\text { real sectors }\end{array}$ & $\begin{array}{l}\text { Insignificant, intensified in before transformational } \\
\text { periods }\end{array}$ & Significant, uniform \\
\hline Local crises & $\begin{array}{l}\text { Episodic, the number increases before systemic } \\
\text { crises }\end{array}$ & $\begin{array}{l}\text { Constant, the frequency of crises does not increase in the } \\
\text { period before systemic crises }\end{array}$ \\
\hline
\end{tabular}


Therefore, the financial and industrial economy is characterized by a constantly excessive amount of financial resources, determines the constant turbulence of its financial flows and the formation of the danger of their movement. If the formation of «soap bubbles» is not characteristic for the industrial economy, then for the financial economy an increase in their number and volume is commonplace at the plateau stage or the recession stage. Moreover, since the «soap bubbles» are part of the mechanism of recovery of laminarity, their formation may occur and occurs at other stages of the economic cycle. The very course of cyclical phenomena in financial economics is changing.

\section{Conclusions}

It has been determined that cyclic processes in the real sector are leveled, while in financial ones they are intensified and sharpened. Given the hyper development of the financial sector, its convergence with the real sector is constantly significant. It should also be noted that the formation of «soap bubbles» supports the possibility of a dichotomy of economic development at any stage of the cycle. At the same time, the effectiveness of financial decisions of this financial sector entity is determined by the achievement of the strategic goal, tactical tasks, socially significant, immediate and final indicators of the effectiveness of the formation and use of financial resources.

So, the article considered certain provisions of the cyclical course of economic processes and analyzed the existing theories of economic cycles and the accounting of safety factors for the movement of financial flows. The financial economy was also defined as a stage of economic development, factors of strengthening (weakening) of interaction of financial flows in the economy were characterized, the specifics of the movement of financial flows in industrial and financial economies were studied. At the end of the study, a comparative characteristic of industrial and financial economies was carried out according to a number of characteristic criteria. Thus, the patterns of the flow of modern financial crises make it possible to form a hypothesis about the existence of a relationship between the characteristics of the circulation of financial resources, the structural relationship between the real and financial sectors and the frequency and depth of recessionary phenomena.

\section{References}

Amadae, S.M. (2018). Computable rationality, NUTS, and the Nuclear Leviathan. In: Bessner, D. And Guilhot, N. (eds.) The Decisionist Imagination: Democracy, Sovereignty and Social Science in the 20th Century. New York, NY: Berghahn Books, in press.

Amicelle, A. (2011). Towards a ‘new’ political economy of financial surveillance. Security Dialogue, 42(2), 161-78.

Arnold, H. (2004). Schumpeter and Methodological Individualism. Journal of Evolutionary Economics, 14(2), 153-156.

Best, J. (2017). Security, economy, population: The political economic logic of liberal exceptionalism, Security Dialogue, forthcoming. https://doi.org/10.1177\%2F0967010617712683

Bodie, Z., Kane, A., Marcus, A. (2005). Investments, (6th ed.) Asia: McGraw-Hill Education.

Bottazzi, G., Secchi, A., \& Tamagn, F. (2008). Productivity, profitability and financial performance. Industrial and Corporate Change, (17) 4, 711-751. https://doi.org/10.1093/icc/dtn027

Brealey, R., Myers, S., Marcus, A. (2007). Solution to Corporate Finance. McGrav-Hill.

Corman, H., Noonan, K., Reichman, N. E., \& Schultz, J. (2012b). Effects of financial insecurity on social interactions. The Journal of Socio-Economics, 41, 574-583. https://doi.org/10.1016/j.socec.2012.05.006

de Goede, M. (2017). Chains of securitization. Finance and Society, 3(2): 197-207. URL: https://hdl.handle.net/11245.1/8016190d$44 f 2-47 f f-b 3 f 5-2 d c 8661 f 6585$

Dalevska, N.; Khobta, V.; Kwilinski, A.; Kravchenko, S. (2019). A model for estimating social and economic indicators of sustainable development. Entrepreneurship and Sustainability Issues, 6(4), 1839-1860. http://doi.org/10.9770/jesi.2019.6.4(21)

Delas, V., Nosova, E., \& Yafinovych, O. (2015). Financial security of enterprises. Procedia Economics and Finance, 27, 248-266. http:// doi.org/10.1016/S2212-5671(15)00998-3 
Dobrovolskienė, N., Tvaronavičienė, M., Tamošiūnienė, R. (2017). Tackling projects on sustainability: a Lithuanian case study. Entrepreneurship and Sustainability Issues, 4(4), 477-488. http://doi.org/10.9770/jesi.2017.4.4(6)

Drobyazko S. (2017). Formation of competitive positions as providing of economic security of insurance companies // International scientific journal “Internauka”. Series: “Economic Sciences” №2. https://doi.org/10.25313/2520-2294-2017-2-4784

Drobyazko S., Hryhoruk I., Pavlova H., Volchanska V., Sergiychuk S. (2019). Entrepreneurship innovation model for telecommunications enterprises. Journal of Entrepreneurship Education, 22(2) URL: https://www.abacademies.org/articles/entrepreneurship-innovation-model-for-telecommunications-enterprises-8097.html

Elton, E., Grube, M., Brown, S., Goetzmann, W. (2003). Modern Portfolio Theory and Investment Analysis. (6th ed.) New York: J. Wiley and Sons.

Fabozzi. J., Modigliani, F., Jones, F., Ferri, M. (2002). Foundations of Financial Markets and Institutions. (3rd ed.) Pearson Education LTD.

Gilbert, E. (2017). Militaries, finance, and (in)security. Finance and Society, 3(2): 180-87. URL: https://www.academia.edu/35777482/ Militaries_finance_and_in_security

Hall, P.A., Soskice, D. (2001). Varieties of Capitalism the Institutional Foundation of Comparative Advantage. Oxford: Oxford University Press.

Hilkevics, S., Hilkevica, G. 2017. New information technologies use for Latvian stock companies financial health evaluation. Entrepreneurship and Sustainability Issues, 5(2), 178-189 http://doi.org/10.9770/jesi.2017.5.2(1)

Haugen, R.A. (2001). Modern Investment Theory. (5th ed.) Great Britain: Upper Saddle River, NJ.

Huber, G., Rehm, P., Schlesinger, M., Valletta, R. (2010). Economic Security at Risk: Findings from the Economic Security Index. URL: https://community-wealth.org/sites/clone.community-wealth.org/files/downloads/paper-hacker-et-al.pdf

Isatayeva, G., Seitova, V., Koptayeva, G., Turlybekova, A., Mutaliyeva, A. (2019). Financing of young knowledge-based companies after the financial crisis: the case of Kazakhstan. Entrepreneurship and Sustainability Issues, 6(3), 1126-1134. http://doi.org/10.9770/ jesi.2019.6.3(12)

Jaconetti, Colleen M., Michael A. DiJoseph, Zoe B. Odenwalder, and Francis M. Kinniry Jr. (2016). From Assets to Income: A GoalsBased Approach to Retirement Spending. Valley Forge, Pa.: The Vanguard Group.

King's College London (2017). Final Report: Study of Typologies of Financing of WMD Proliferation, King's College London, London Langenohl, A. (2017). Modular sovereignty, security, and debt: The Excessive Deficit Procedure of the European Union. Finance and Society, 3(2): 124-42. https://doi.org/10.2218/finsoc.v3i2.2573

Langley, P. (2015). Liquidity Lost: The Governance of the Global Financial Crisis. Oxford: Oxford University Press. https://doi. org/10.1111/1745-5871.12130

Laster, David, Nevenka Vrdoljak, and Anil Suri (2016). Strategies for Managing Retirement Risks. The Journal of Retirement 4(1), 11-18. https://doi.org/10.3905/jor.2016.4.1.011

Masood, O., Tvaronavičienė, M., Javaria, K. 2019. Impact of oil prices on stock return: evidence from G7 countries. Insights into Regional Development, 1(2), 129-137. https://doi.org/10.9770/ird.2019.1.2(4)

Massumi, B. (2014). The Power at the End of the Economy, Durham, NC: Duke University Press

McCloskey, D.N. (2016). Bourgeois Equality: How Ideas, Not Capital or Institutions, Enriched the World. Chicago, IL: University of Chicago Press.

Nanto, D. K. (2011). Economics and National Security: Issues and Implications for U.S. Policy, Congressional Research Service. Available on the Internet: https://www.fas.org/sgp/crs/natsec/R41589.pdf

Naudé, W., \& Szirmai, A. (2013). Industrial policy for development. United Nations University. Available on the Internet: http://pdfs. semanticscholar.org/8f69/e732f966d6f39598f50c551342d22a1fffd1.pdf

Rudman, Steve. (2013). Hope, Access and the Potential for a Better Tomorrow. Home Forward. Retrieved July, 2013. Available on the Internet: http://homeforward.org/home-forward/welcome 
Sachs, J.D. (2016). Happiness and sustainable development: Concepts and evidence. World Happiness Report 2016. Available on the Internet: http://flexclay.com.au/wp-content/uploads/2016/07/report1.pdf

Standard and Poor's (2007). Public Finance Criteria. New York.

Tvaronavičienė, M. (2019a). Insights into global trends of capital flows' peculiarities: emerging leadership of China. Administratie si Management Public, (32), pp. 6-17, https://doi.org/10.24818/amp/2019.32-01

Tvaronavičienė M. (2019b). Leadership for Critical Infrastructure Protection. In: Strielkowski W. (eds) Sustainable Leadership for Entrepreneurs and Academics. Springer Proceedings in Business and Economics. Springer, Cham. https://doi.org/10.1007/978-3-03015495-0_40

UN Security Council (2017). Final Report of the Panel of Experts submitted pursuant to resolution 2276 (2016), United Nations, New York URL: https://www.un.org/securitycouncil/sanctions/1718/panel_experts/reports

Wallick, Daniel W., Julieann Shanahan, Christos Tasopoulos, and Joanne Yoon (2012). The Global Case for Strategic Asset Allocation. Valley Forge, Pa.: The Vanguard Group.

Wei, Bu (2015). Research on China Industrial Security Early Warning Based on BP Neural Network. Available on the Internet: https:// link.springer.com/chapter/10.1007/978-3-662-44085-8_28

Wit, B., Meyer, R. (2005). Strategy Synthesis. Resolving strategy. Paradoxes to Create Competituve Advantage. Thomson Learning

World Economic Forum (2018). Global Competitiveness Report 2017- 2018. Available on the Internet: http://reports.weforum.org/globalcompetitiveness-index-2017-2018/infographics/

Yan, I. (2012). Risk to global financial stability have increased, Available on the Internet: http://news.xinhuanet.com/english/world/201201/24/c_131375861.htm

Short biographical note about the contributors at the end of the article:

Liudmyla KATAN, Doctor in Economics, Professor, Head the Department of Finance, Banking ang Insurance, Dnipro State Agrarian and Economics University

ORCID ID: orcid.org/ 0000-0001-5657-3105

Iuliia MASIUK, PhD in Economics, Professor the Department of Finance, Banking ang Insurance, Dnipro State Agrarian and Economics University

ORCID ID: orcid.org/0000-0001-6445-806X

Tetyana OLIYNIK, Ph.D in Economics, Associate Professor the Department of Economics, Oles Honchar Dnipro National University ORCID ID: orcid.org/0000-0003-1224-3790

Oleg OLIYNIK, Ph.D in Economics, Associate Professor the Department of Finance, Banking ang Insurance, Dnipro State Agrarian and Economics University

ORCID: ID: orcid.org/0000-0001-5657-3105

Volodymyr ZABLOTSKYI, Doctor of Science in State Administration, Associate Professor, Professor the Department of Civil Service and Management of Educational and Social Institutions, State Institution "Luhansk Taras Shevchenko National University"

ORCID ID: orcid.org/0000-0003-1032-8993

Register for an ORCID ID:

https://orcid.org/register

This work is licensed under the Creative Commons Attribution International License (CC BY). http://creativecommons.org/licenses/by/4.0/ 